\title{
NEW COMBINATIONS IN CYRTOCHILUM (ORCHIDACEAE: ONCIDIINAE)
}

\author{
STIG DALSTRÖM
}

\begin{abstract}
2304 Ringling Boulevard, unit 119, Sarasota FL 34237, USA; Lankester Botanical Garden, University of Costa Rica, Cartago, Costa Rica; National Biodiversity Centre, Serbithang, Bhutan

stigdalstrom@gmail.com
\end{abstract}

\begin{abstract}
Two species, originally described as Odontoglossum amphiglottis and Odontoglossum sodiroi are here transferred to Cyrtochilum (Orchidaceae: Oncidiinae), based on molecular data and morphological features, accompanied by brief discussions about their taxonomic background and natural history, and illustrated with line drawings and photographs. Both species were previously considered to be synonyms of $C$. ramosissimum by the author of this paper and others, due to limited access of type material. But recent field discoveries reveal that a much stouter growth habit and distinctly corymbose inflorescences distinguish $O$. amphiglottis from $C$. ramosissimum. In the case of $O$. sodiroi the smoothly rounded pair of basal lip calli, which are marginally covered externally by the ventral flanks of the column, distinguish this species from C. ramosissimum, which has more or less denticulate basal callus keels on the lip, and where the ventral columnar flanks are marginally placed between these keels.
\end{abstract}

KeY Words: Cyrtochilum, new combinations, Oncidiinae, Orchidaceae

Introduction. The genus Cyrtochilum Kunth never stops presenting surprises. Striking, as well as insignificant new species appear in a seemingly never-ending flow. Some new names turn out to be synonyms of older ones, and some older synonyms turn out to represent distinct species as we go back and re-study the type specimens, decipher obscure descriptions and compare them with freshly made field observations.

John Lindley (1852) described Odontoglossum ramosissimum Lindl. (Fig. 1-3), from a plant collected in Venezuela by Jean Linden (J. Linden 661, K-L, W). Lindley placed the plant in Odontoglossum Kunth, based primarily on the flower morphology. The shape of the column and the lip were early on considered important taxonomic features, and in Odontoglossum the lip and column were supposed to be "parallel" (in a very broad sense). But then it was discovered that many not closely related plants also produce flowers with a similar shape. In addition, not all true Odontoglossum species share the same lip-column structure and angle. Based on a broader morphological concept, including vegetative features in combination with molecular data (Williams et al. 2001), O. ramosissimum together with many closely related species were transferred to Cyrtochilum in a synopsis of the genus (Dalström 2001). In this synopsis O. amphiglottis Rchb.f. (originally described as "amphiglottii", which is believed to be a misspelling) and Odontoglossum sodiroi Schltr., were included as synonyms of $C$. ramosissimum.

In the case of Odontoglossum sodiroi, Rudolf Schlechter based his description on two different Ecuadorean collections made by the Jesuit priest Luis Sodiro (1836-1909), which unfortunately represent two different species; L. Sodiro 112 $(\mathrm{BR})=$ Cyrtochilum angustatum (Lindl.) Dalström (Fig.4), and L. Sodiro 23b (Fig. 5-7) represents what has long been known as Odontoglossum, and later Cyrtochilum ramosissimum in horticulture and various literature (Bockemühl 1989, Dalström 2001, 2010). After more detailed analysis of type specimens and other collections it has become clear that L. Sodiro 23b, which is distributed from Colombia to central Peru, in fact represents a distinct species that is different from the typical C. ramosissimum, which is only reported from Venezuela. The main difference being that the basal and ventral flanks of the column lay on the outside of the basal lip callus in $O$. sodiroi, versus being held between the basal callus keels in C. ramosissimum. 

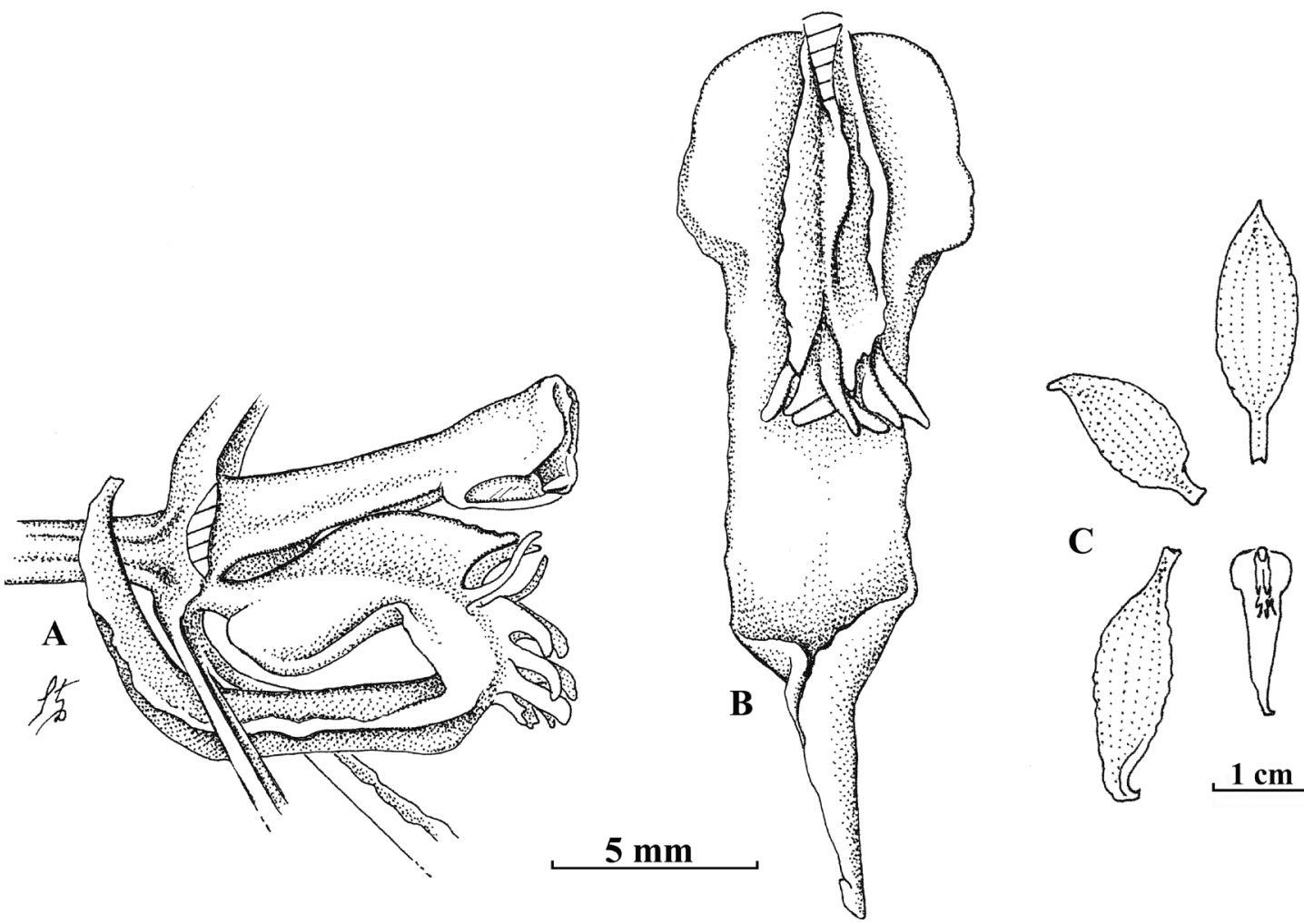

C

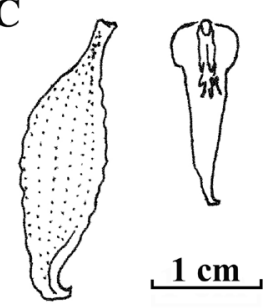

FiguRE 1. Cyrtochilum ramosissimum (Lindl.) Dalström. A. Lip column lateral view. B. Lip dorsal view. C. Flower dissected. Drawn from N. Funck \& L. J. Schlim 1041 (W) by Stig Dalström.

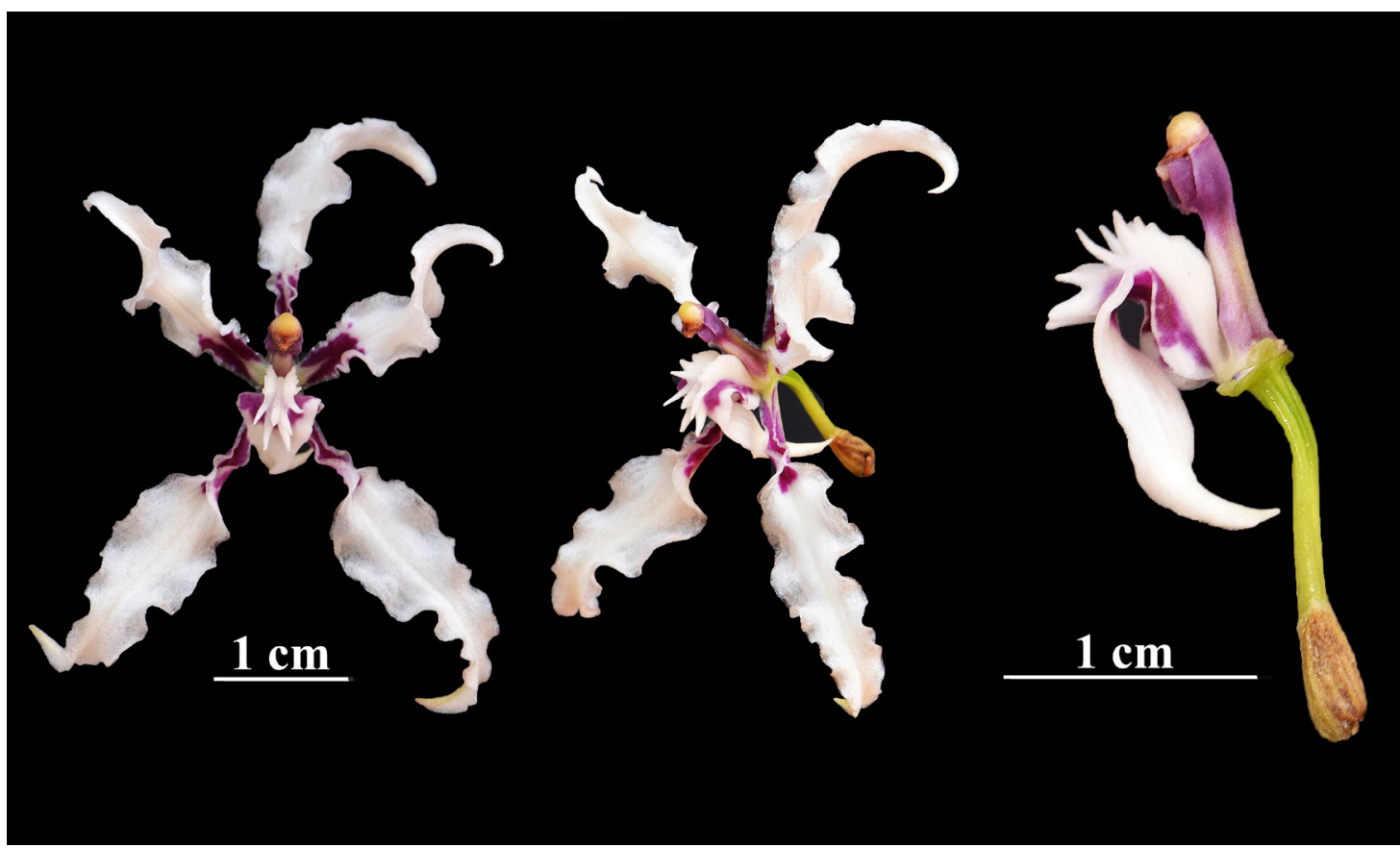

FiguRe 2. Cyrtochilum ramosissimum. Plant from Venezuela. Photo by Carlos Jerez. 
The basal and dominating callus keels in $O$. sodiroi emerge abruptly near the base of the lip and are perfectly smooth and rounded (Fig. 6-7), as opposed to emerging more gradually at a short distance from the base of the lip and being more or less denticulate near the apex in C. ramosissimum. But because L. Sodiro 112 is listed first in Schlechter's description it was originally considered by Dalström $(2001,2010)$ that it would represent the type of $O$. sodiroi, which therefore constitutes a synonym of $C$. angustatum. The L. Sodiro $23 b$ specimen would then become a new species. But Schlechter mentions in the type description that $O$. sodiroi is similar to $O$. ramosissimum, and may be the same thing, but that it differs in the base of the lip not being cordate (heart-shaped), and the callus

$\rightarrow$ Right, Figure 3. Cyrtochilum ramosissimum. Plant from Venezuela. Photo by Leonore Bockemühl, provided by Karlheinz Senghas.
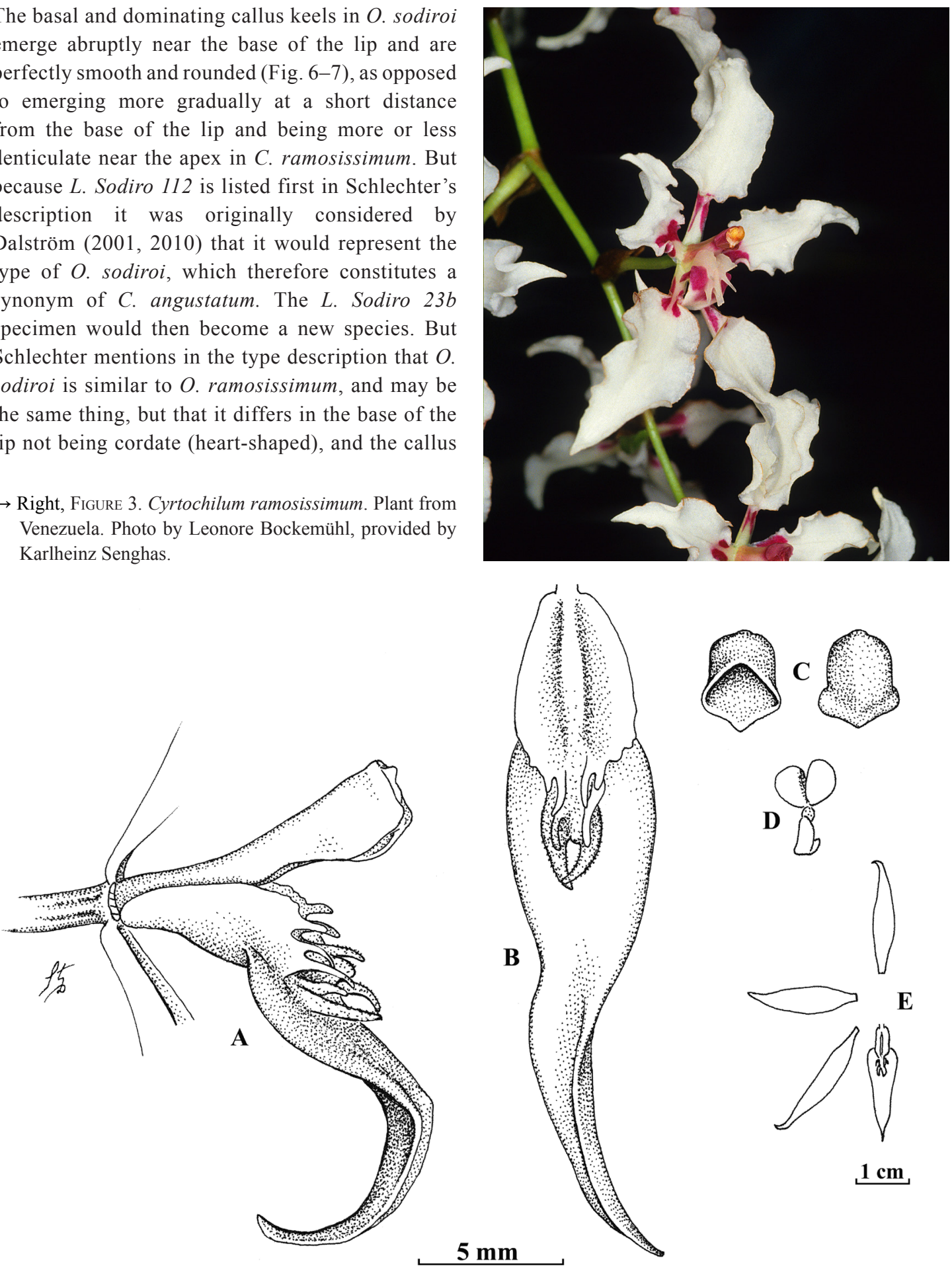

Figure 4. Cyrtochilum angustatum (Lindl) Dalström. A. Lip column lateral view. B. Lip dorsal view. C. Anther cap, front and back views. D. Pollinarium. E. Flower dissected. Drawn from L. Sodiro 112 (BR) by Stig Dalström. 


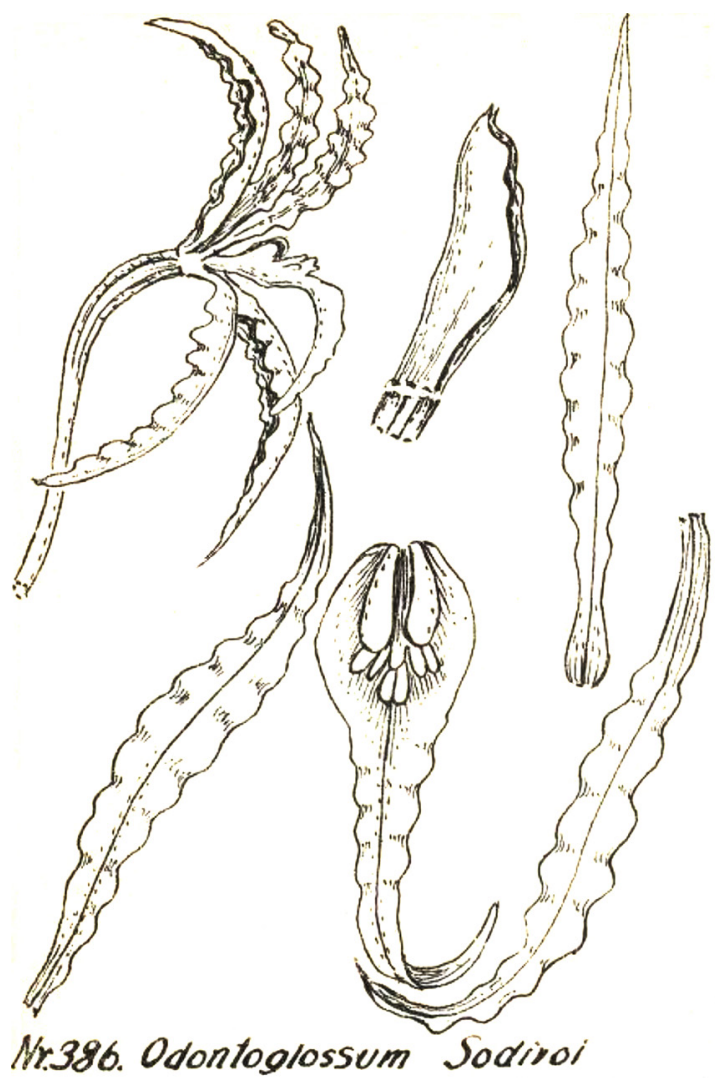

Figure 5. Cyrtochilum (as "Odontoglossum") sodiroi (Schltr.) Dalström. Based on L. Sodiro 23b, published in Repert. Spec. Nov. Regni Veg., Beih. 57, plate 99, no. 386 (1929).

being glabrous and shaped differently. This is a rather confusing statement because the spreading basal lobes of the lip of the true C. ramosissimum from Venezuela are not cordate, but hastate to indistinctly cuneate. The highly variable lip base of what $L$. Sodiro $23 b$ represents in the wild, on the other hand, has spreading side-lobes that can be cordate as well as hastate to cuneate, and is often virtually identical with the illustration of $O$. sodiro $i$ in Schlechter ex Mansfeld (1929) (Fig. 5). The basal lobes of the lip of C. angustatum (L. Sodiro 112), (Figs. 4, 9), on the other hand, are erect and fused to the lip callus and structurally very different from both $L$. Sodiro $23 b$ and C. ramosissimum. The lip callus is also pubescent as opposed to glabrous for the other two. It is therefore unclear why Schlechter mentions that the callus of $O$. sodiroi differs from
C. ramosissimum by not having a cordate lip base (which $L$. Sodiro $23 b$ in fact sometimes has, but not so for $C$. ramosissimum). Schlechter also points out that the lip callus for his "O. sodiroi" is glabrous thus suggesting that the lip callus of $C$. ramosissimum is not, when in fact they both have glabrous lip calli. The only member of this triad that has a pubescent lip callus is $C$. angustatum (hence L. Sodiro 112). In order to straighten out this confusion it seems therefore reasonable and pragmatic to accept $L$. Sodiro $23 b$ as what Schlechter envisioned as being $O$. sodiroi and treat it as a distinct species that needs to be transferred to Cyrtochilum. The name "sodiroi" has been used in publications for this taxon (Dodson \& Dodson 1984), and is currently becoming more and more used by people, so it is proposed here to attach this name permanently for this species. The transfer to Cyrtochilum is made below.

In the synopsis of the genus Cyrtochilum (Dalström 2001) it is mentioned that Odontoglossum amphiglottis (Fig. 8, 10) differs from $C$. ramosissimum by a smaller habit with fewer flowers on a shorter inflorescence, differences which do not justify specific status. This statement was based on studies of the poor and insignificant type specimen of $O$. amphiglottis in the Museum of Natural History in Vienna (B. Rözl s.n. W). However, this statement could not be farther from the truth. Recent observations of living plants in the field by Fernando Ramírez, Esteban Domínguez, Sebastián Moreno, Sebastián Vieira and others show a very large and sturdy-looking plant that displays the distinguishing floristic features of $O$. amphiglottis, and is also coming from the same general area as the type collection (Fig. 10). The straight and erect corymbose inflorescence of $O$. amphiglottis differs from the generally laxly arching and loosely branched inflorescence of the sympatric $O$. sodiroi (Fig. 11). The flowers of the former appear to be consistently rosy purple, while the flowers of the latter vary considerably from white to pale yellow with purple to brown spots and stripes (Fig. 7, 1112). It is therefore concluded here that these species represent distinct taxa, and that they both need to be authoritatively transferred to Cyrtochilum, which is made below. 

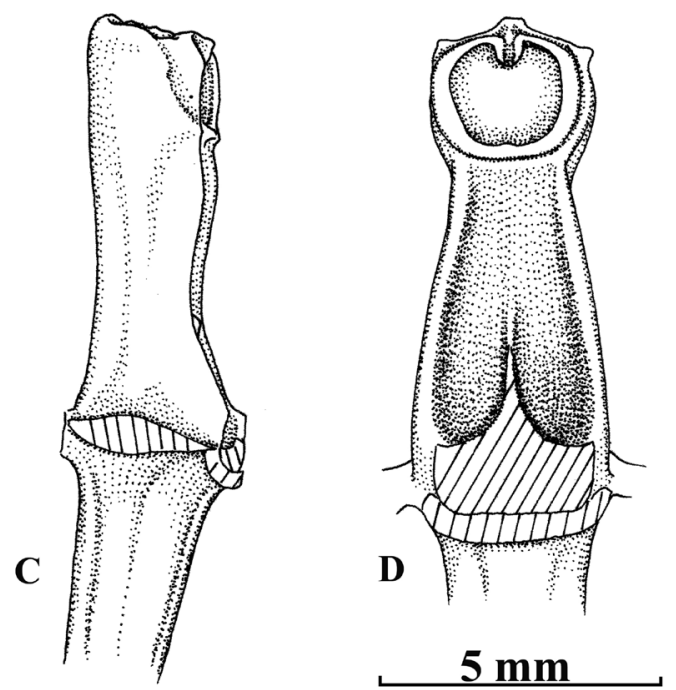

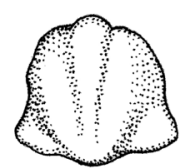

E
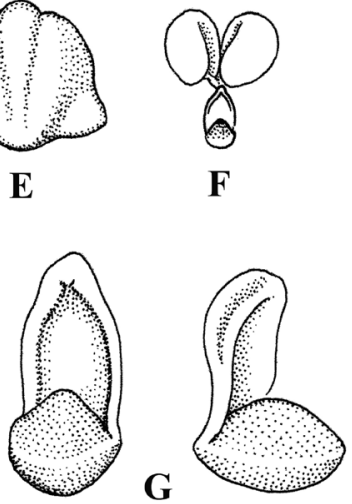

$1 \mathrm{~mm}$
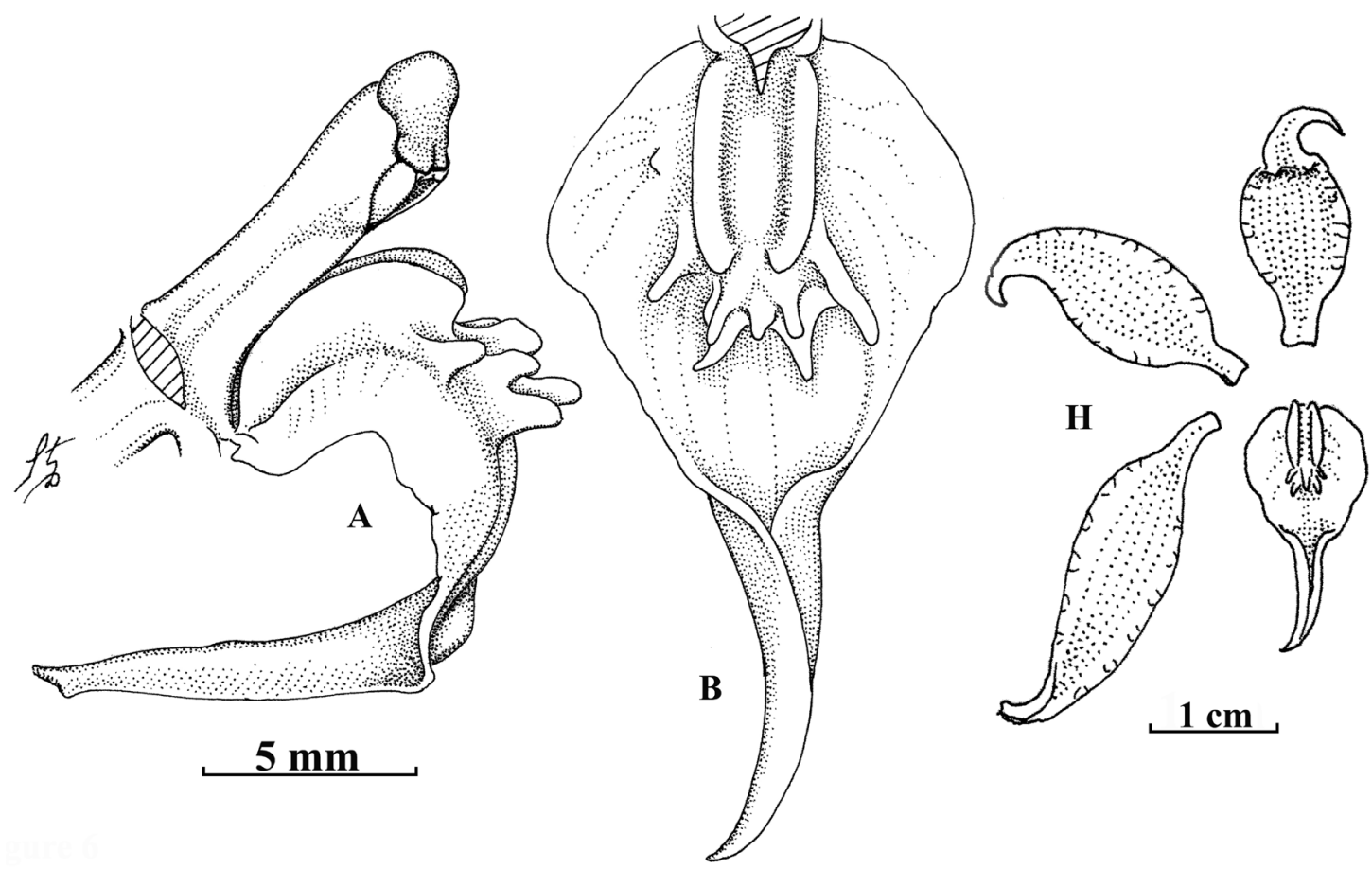

Figure 6. Cyrtochilum sodiroi (Schltr.) Dalström. A. Lip column lateral view. B. Lip dorsal view. C. Column lateral view. D. Column ventral view. E. Anther cap front view. F. Pollinarium back view. G. Stipe and viscidium front and back views. H. Flower dissected Drawn from S. Dalström 606 (SEL) by Stig Dalström. 


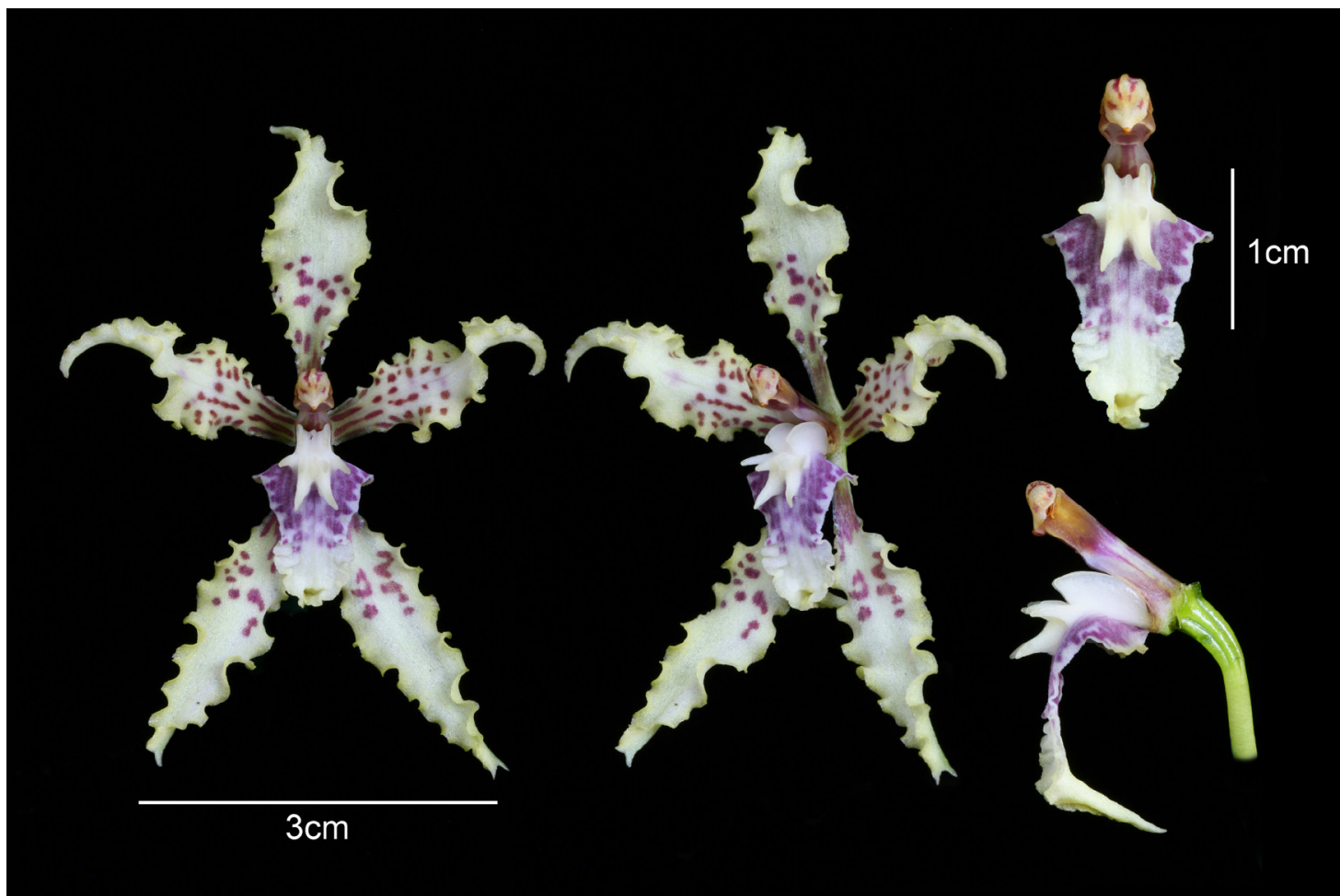

Figure 7. Cyrtochilum sodiroi (Schltr.) Dalström. Plant cultivated and photographed by Guido Deburghgraeve (G. Deburghraeve 410).

\section{TAXONOMIC TREATMENT}

Cyrtochilum amphiglottis (Rchb.f.) Dalström, comb. nov. Odontoglossum amphiglottis Rchb.f., Linnaea 41. 1877. TYPE: Colombia, Medellín, B. Rözl s.n. (holotype: W). Fig. 8, 10.

Cyrtochilum sodiroi (Schltr.) Dalström, comb. nov. Odontoglossum sodiroi Schltr., Repert. Spec. Nov. Regni. Veg. Beih. 8: 101. 1921. SYNTYPES: Ecuador. Pichincha: in silvis subandinis montis Corazon-Miligally, L. Sodiro 112 (BR); Ecuador. [Napo:] in silvis subandinis Andium Orientalium supra Oyacachi, L. Sodiro 23 b (holotype: B, probably destroyed; illustration of the type, selected here as the lectotype: Odontoglossum sodiroi. Repertorium Specierum Novarum Regni Vegetabilis, Beihefte 57, plate 99 , no. 386. Fig. 5-8, 11-12.

The Biblioteca Ecuatoriana Aurelio Espinosa Pólit (QPLS) in Quito, Ecuador, hosts a number of Sodiro's specimens, which have not been seen by the author. If an isotype of Sodiro $23 \mathrm{~b}$ would possibly be found there, this would supersede the present lectotypification.

ACKNOWLEDGMENTS. I thank the curators of the following herbaria for allowing access to important specimens: AMES, BR, BM, COL, F, HEID, JAUM, K, K-L, M, MO, MOL, NY, QCA, S, SEL, US, USM and W. I also thank Guido Deburghgraeve for his help with the introduction to the herbarium in Meise, and Wesley Higgins for viewing the manuscript.

\section{LITERATURE CITED}

Bockemühl, L. (1989). Odontoglossum, Monographie und Ikonographie - a monograph and iconograph. Hildesheim, Germany: Brücke-Verlag Kurt Schmersow.

Dalström, S. (2001). A synopsis of the genus Cyrtochilum (Orchidaceae; Oncidiinae): taxonomic reevaluation and new combinations. Lindleyana, 16(2), 56-80. 


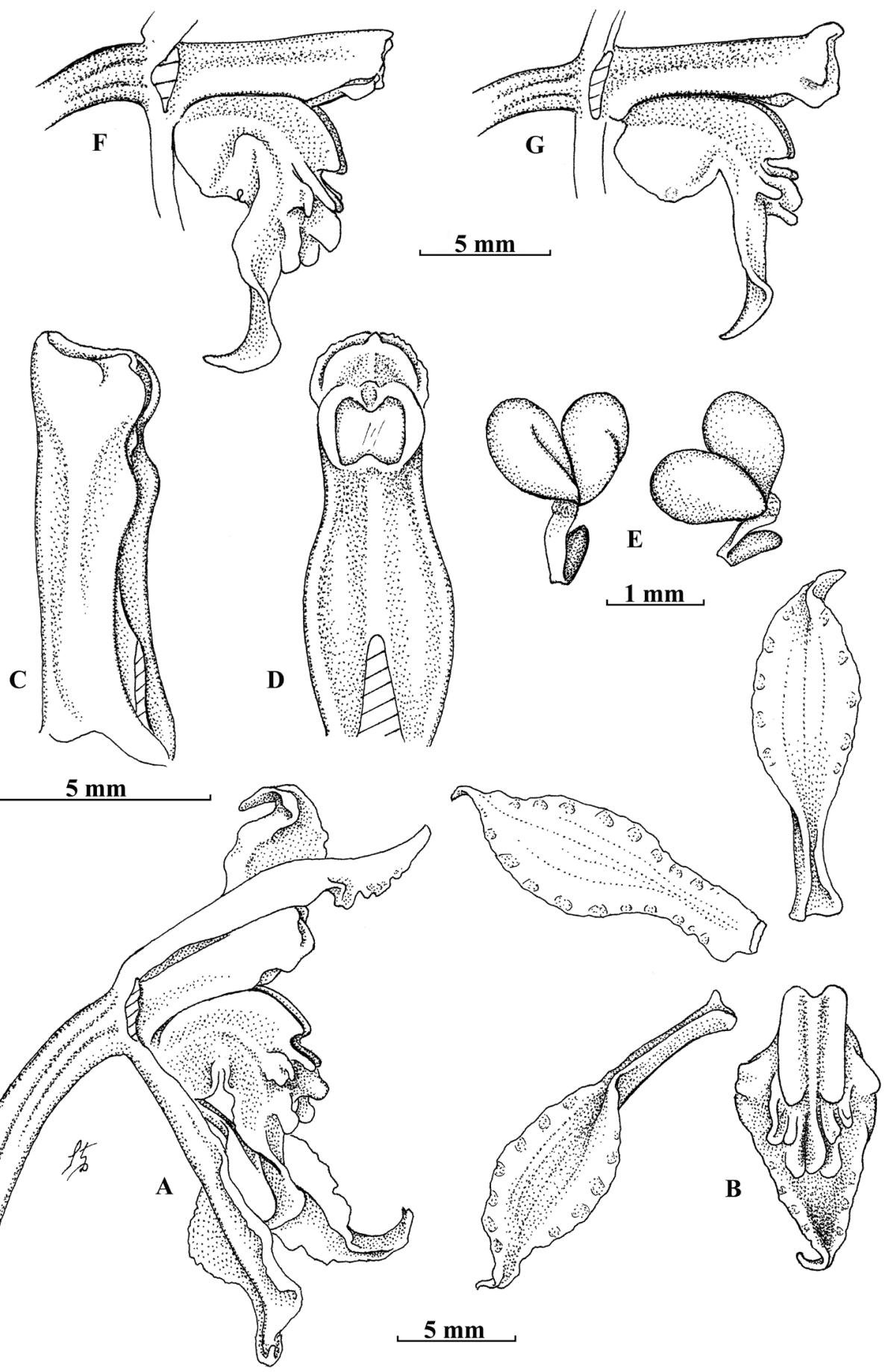

FiguRE 8. Cyrtochilum amphiglottis (Rchb.f.) Dalström. A. Flower with right petal removed, lateral view. B. Flower dissected. C. Column lateral view. D. Column ventral view. E. Pollinarium front-angled and back-angled views. F. Column lip lateral view. Drawn from Schmidtchen s.n. (W) by Stig Dalström. G. Lip column lateral view. Drawn from B. Rözl s.n. (W) by Stig Dalström. 


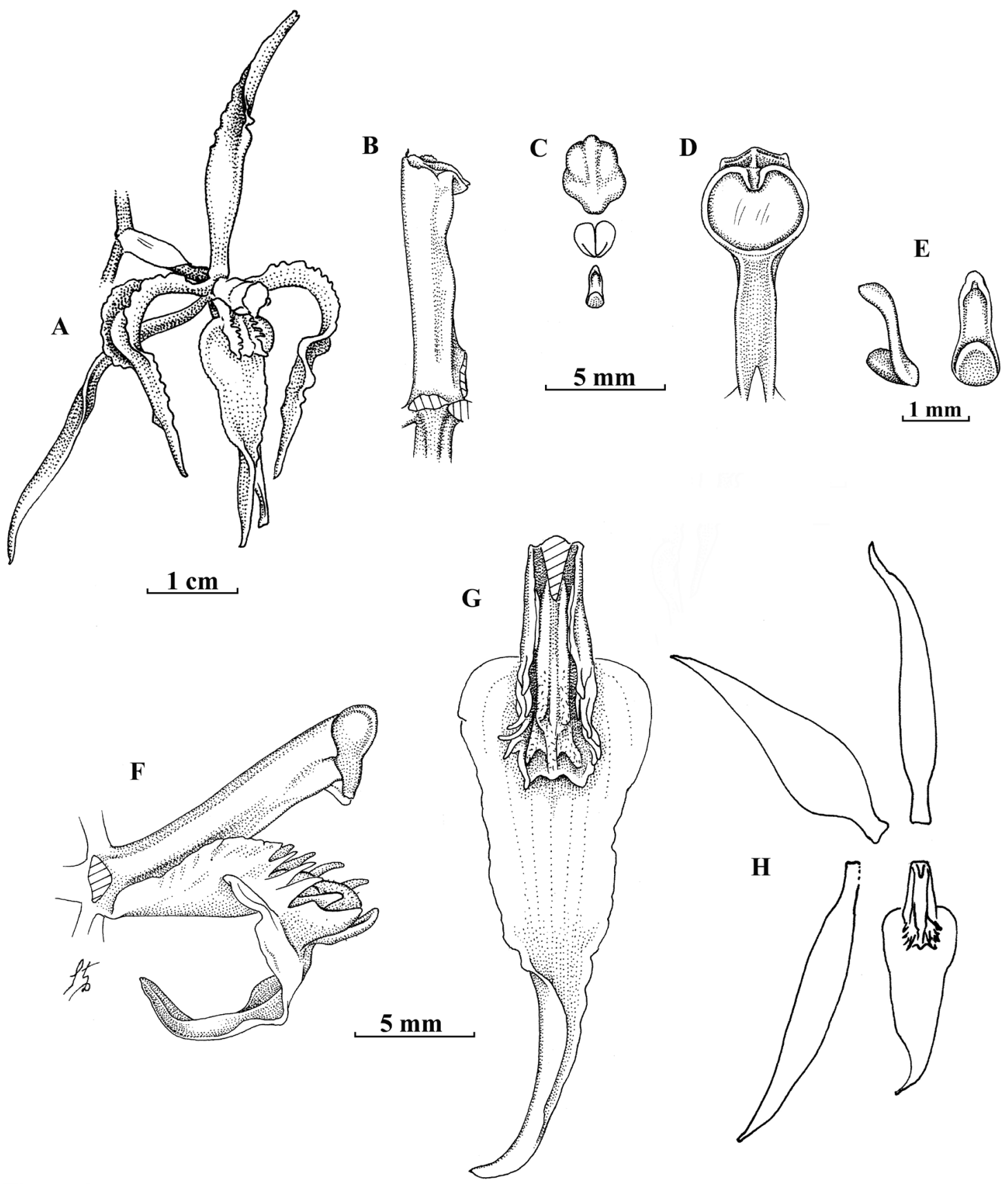

Figure 9. Cyrtochilum angustatum (Lindl.) Dalström. A. Flower front-angled view. B. Column lateral view. C. Anther cap front view and pollinarium back view. D. Column ventral view. E. Stipe and viscidium lateral and back views. F. Lip and column lateral view. G. Lip dorsal view. H. Flower dissected. Drawn from S. Dalström 001 (SEL) by Stig Dalström. 


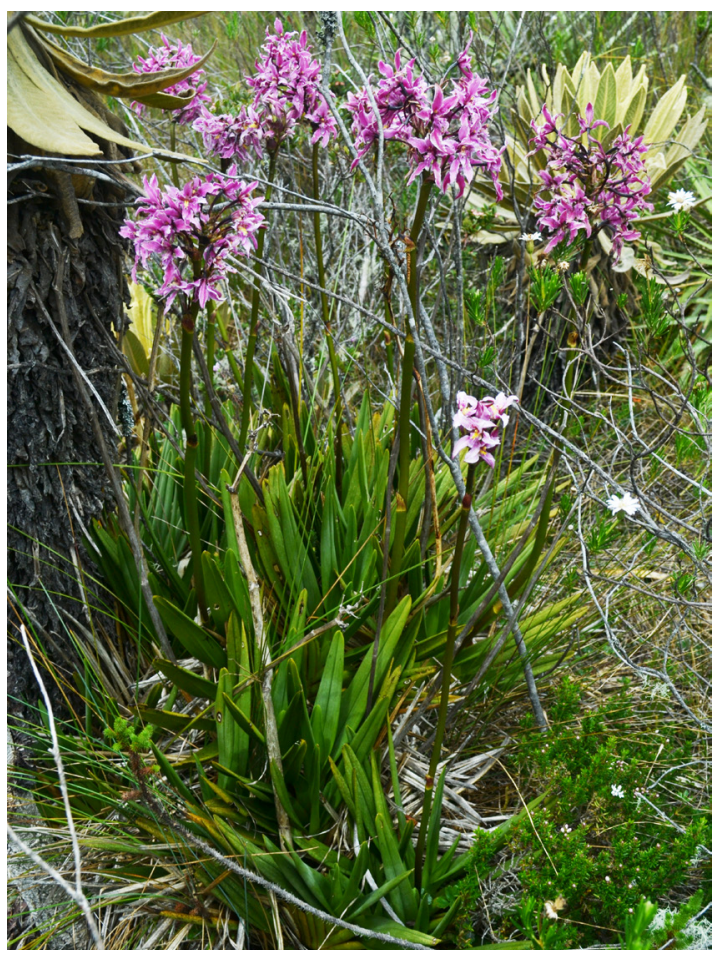

FIGURE 10. Plant of Cyrtochilum amphiglottis (Rchb.f.) Dalström, from the natural habitat in the department of Antioquia, Colombia. Photo by Esteban Dominguez.

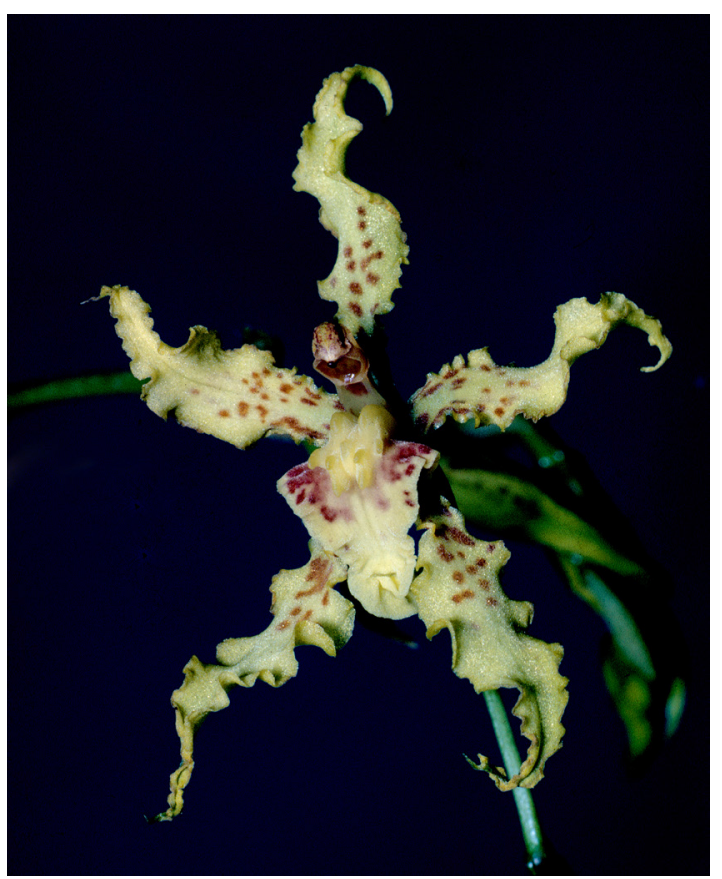

FIGURE 12. Cyrtochilum sodiroi (Schltr.) Dalström. Flower photographed by Gilberto Escobar (G. Escobar 809).

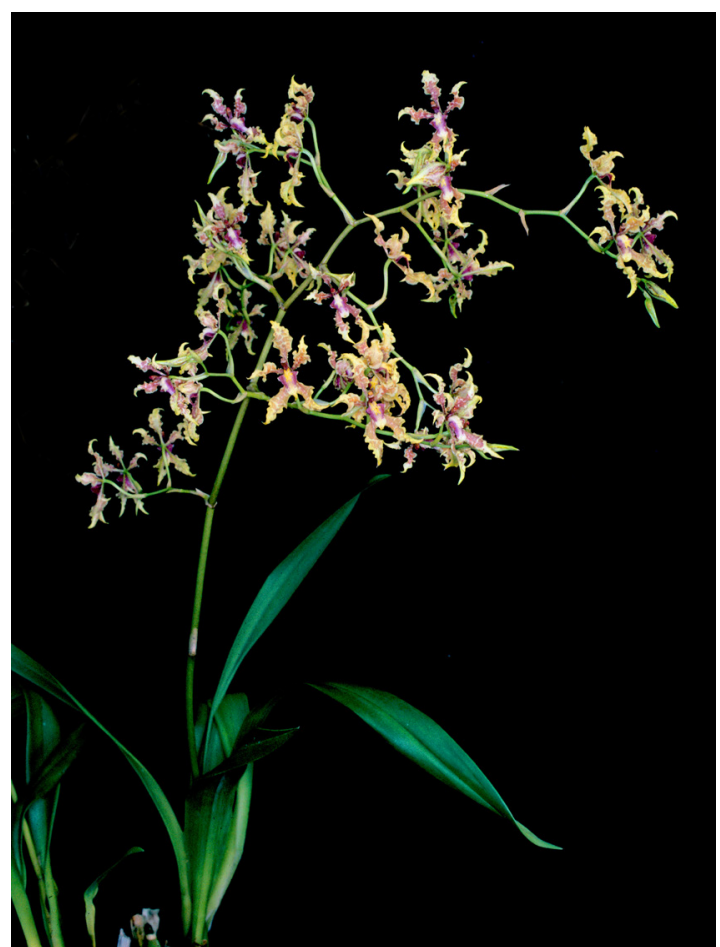

FIgURE 11. Cyrtochilum sodiroi (Schltr.) Dalström. Plant cultivated and photographed by Jan Sönnemark.

Dalström, S. (2010). Cyrtochilum Kunth. In: G. Harling \& C. Persson (Eds.), Flora of Ecuador, volume 87, part 225(3): Orchidaceae genera Cyrtochiloides-Epibator (pp. 18-198). Saint Louis, U.S.A.: Missouri Botanical Garden.

Dodson, C. H. \& Dodson, P. M. (1984). Odontoglossum sodiroi. Icones Plantarum Tropicarum 10: plate 966.

Lindley, J. (1852). Odontoglossum ramosissimum. Folia orchidacea, part 1: 16. London, England: J. Matthews.

Schlechter, R. \& Mansfeld, R. (1929). Odontoglossum sodiroi. Repertorium Specierum Novarum Regni Vegetabilis, Beihefte 57, plate 99, no. 386.

Williams, N. H., Chase, M. W., Fulcher, T. \& Whitten, W. M. (2001). Molecular systematic of the Oncidiinae based on evidence from four DNA sequence regions: expanded circumscriptions of Cyrtochilum, Erycina, Otoglossum, and Trichocentrum and a new genus (Orchidaceae). Lindleyana, 16, 113-139. 
